\title{
Living on the Edge: Interrogating Migrant Labourer Lives of Bengaluru/Bangalore
}

\author{
Navami T. S. \\ PhD Scholar, Department of Humanities and Social Sciences, IIT Kharagpur \\ Email: navamiskumar@gmail.com
}

\begin{abstract}
This paper proposes to create a discourse of migrant labourers in the city of Bengaluru/Bangalore, especially during the current period of crisis ensued by COVID-19 pandemic. Despite being an essential part of the informal sector economy these workers are often rendered invisible from the urban social, cultural and political spaces of this global city. The United Nations Conference on Housing and Sustainable Development (Habitat III), held in Quito, Ecuador in October 2016 declared the New Urban Agenda (NUA) - that was adopted as the guideline for urban development for the next twenty years - with the vision of 'cities for all'. But in reality, for their regional, linguistic, cultural, class and caste differences, the migrant labourers in the city are marginalized from the mainstream urban scene. The paper investigates the historiography of the migrant labourers in the city to interrogate the space they occupy in Bengaluru/Bangalore. Some of the important questions the paper attempts to grapple with are also about their fight for survival amidst the outbreak of COVID-19 pandemic and the relief measure responses from the state. Evidences show, the immigrant labourers are perceived as the city's necessary 'Other' who are needed to build the city but barely finds any representation in the planning grids of urban architects. Their direct experiences and negotiations with 'the lived city', available from news archives and other secondary sources, will be interrogated through the lens of 'the Right to the City', a concept introduced by Henri Lefebvre. The paper attempts to explore if they have any agency to assert their rights to the city and become a meaningful stakeholder in the democratic control over Bengaluru/Bangalore.
\end{abstract}

Keywords: Migrant labourers, COVID-19, Space, the Right to the City

\section{Introduction}

Bengaluru/Bangalore, a rapidly evolving metropolitan city that functions as the state capital of Karnataka (India), has always enamoured the world with its peerless performance at various monumental events in history. During the early phase of rampant coronavirus infections in India, the city of Bengaluru was popularized as a competent model for other cities to follow while fighting COVID-19 pandemic and the subsequent scenario of chaos and uncertainties. The first Covid positive case emerged in the city on 10 March 2020. Since then, the Karnataka state government has been cautious in devising plans for efficiently monitoring the crisis situation. But by June, due to several social, political and economic reasons, the city became a hotspot where the number of people testing positive for COVID-19 was increasing on a daily basis. This resulted in a tectonic shift in the economic structure of the city, which in turn, affected the global economy, where the dynamic presence of Bangalore is felt since the advent of globalization and neoliberalization in 1990 s.

(C) AesthetixMS 2020. This Open Access article is published under a Creative Commons Attribution Non-Commercial 4.0 International License (http://creativecommons.org/licenses/by-nc/4.0/), which permits non-commercial re-use, distribution, and reproduction in any medium, provided the original work is properly cited. For citation use the DOI. For commercial re-use, please contact editor@rupkatha.com. 
Upon close investigation one can observe that though being a technopolis of global standards, the space of the city of Bengaluru/Bangalore (Though the name of the city was changed to Bengaluru in 2006, 'city'zens address it as 'Bangalore'. This paper uses both the names to show the duality/dichotomy of the name and character of the city.) is deeply entrenched with varied kinds of social inequalities and cultural divides, which have amplified with the neocapitalistic turn of this century. The migrant labourers (were collectively called as 'guest' workers during lockdown), an inevitable presence in the urban space of Bengaluru/Bangalore, encounters social and spatial exclusion from the mainstream city on an everyday basis. The narratives of their grievous suffering and diligent fight for survival against Covid pandemic manifest the incompetence and ineptness of the state in adequately representing them within the framework of urban governance and public health care policies. Thus, it is pertinent to interrogate the space occupied by migrant labourers in this global city. The questions that this paper tries to grapple with are about the unlauded histories of immigrant labourers, the constant 'Other'ing of these labourers within the urban (social) space, and the role of the state in emphasizing their 'Rights to the City' of Bengaluru/Bangalore, especially during the pandemic period.

\section{Living Histories on the Edge}

The paper investigates the historiography of migrant labourers in Bengaluru/Bangalore to interrogate the space they occupy in the city. It is fascinating to note that the history of these labourers is inextricably interwoven with the history of the city itself. Thus, it would be inappropriate to neglect and marginalize their historicity within the urban context. Migration from neighbouring regions of Bangalore began since the establishment of south India's largest British Cantonment at Ulsoor in 1809, after the fall of Tipu Sultan. But the landmark events that radically changed the urban economy and space, by alluring migrants from various parts of the country, are: firstly, the industrialization of the city in 1950s, and secondly, the advent of neoliberal economic reforms, globalization, and the revolutionary boom in cyber industry in 1990s.

H. Shashidhar, Ex-Director of Census Operations in Karnataka, has written "A History of Migration to Bangalore" (2003) based on the Census data mustered between 1951 and 2001. The text historicizes the phenomenon of internal migration which has brought a momentous shift in the demographic profile and the socio-economic development of the city. According to the 1951 Census, there were about 3 lakh migrants in the city, and one can find an alarming increase in this number in the later Censuses conducted. A sense of inadequacy and frustration on their inability to attain their aspirations was one of the main reasons that forced the labourers to move out of their hometowns. A high percentage of this migrant population was illiterate because of which they were categorized as unskilled labourers, who mostly received employment as contractual workers in automotive, manufacturing and construction industries, and also as street vendors, autorickshaw drivers, gardeners and domestic helps. By 1991, there were about 11 lakh migrants in Bangalore, out of which 54.45 percent have come from other districts of Karnataka and 44.04 percent from other states like Tamil Nadu, Kerala, Maharashtra, Goa, Andhra Pradesh and Telangana (Shashidhar, 2003, pp. 70-84).

The earlier labour settlements were primarily composed of Tamil immigrants (Pariahs by caste), who hailed from the North and South Arcot districts of Madras. These 'lived' spaces (an extension of the Lefebvrean idea of 'the lived city'), consisting of mud huts, were rendered invisible from the mainstream physical space of the city as they extended behind 'higher' homes and shops as is explained by Gertrude M. Woodruff in her essay, "Family Migration into Bangalore" (1960). Such a neighbourhood of mud huts was referred to as Jopadi. It was in 1920 s 
that the earliest labour settlement was established on an empty field surrounded by paddy fields and 'the Maharaja stables'. Most of the inhabitants were employed by the City Corporation as gangmen, by hotels as servants, or by construction contractors as coolies. Later, many families from Café Street jopadi were shifted to a Corporation Housing Project located two miles nearer to the edge of the city (Woodruff, 1960, pp. 163-72). That was how they were tactically pushed to the peripheries of this growing metropolis and detached from participating in the process of urban decision making. Woodruff brings the history of Café Street jopadi (that might have located towards the north western part of today's Bengaluru) to the forefront in great detail. This helps in maintaining an understanding about former migrant ghettos that were either pushed or erased away from the urban frontier. Thus, the history of migrant labourers and their social exclusion in Bengaluru/Bangalore can be traced back to the first wave of immigration into the city.

It is important to ask how the urban architects conceive and plan the city incorporating the lives of migrant labourers into the radar of town planning and infrastructure policies. The inflow of skilled and unskilled migrant labourers to the city gained momentum with the industrialization of Bangalore in 1950s. This phenomenon generated a great demand for housing and residential spaces. The City Improvement Trust Board then focused on devising housing plans for two classes of new entrants to the city, namely the public sector workers and the government servants (Nair, 2005, pp. 121-65). However, the unskilled migrant labourers, though part of these new entrants, found no representation in such spatial planning processes. The contemporary scenario also shows how the image of an immigrant labourer is still blurred in the planning imaginary. They are neither given 'authorized' spaces nor provided with basic amenities to construct secure and hygienic settlements; often they are pushed away from the center to the margins of the city, where medical, educational and other necessary resources are available sparsely. For instance, labour shelters like Kenchenahalli and Aditya Layout in Rajeshwari Nagar - located towards the western edges of the city in a hard-to-reach remote area - are deprived of electricity, water and sanitation facilities. Open defecation has become a common practice for them (Smita et al., 2014, pp. 112-130), which is condemned as a 'lowly' and 'savage' socio-cultural behaviour by the hegemonic urban civil society. The elite middle class fails to acknowledge the fact that this working class community neither have access to primary education nor to learning cultural and social etiquettes so that they 'behave in a cultured or civilized manner' in the society. A migrant labourer is perceived as the 'Other', who does not belong to the mainstream urban space. Thus, it becomes apparent that COVID-19 pandemic has added to the already existing dilemmas in the lives of these labourers in Bengaluru/Bangalore, by alienating them further from the urban social practices.

\section{Precarity amidst Pandemic}

During the nationwide lockdown from 25 March till 31 May (2020), the migrant labourers were apprehensive about employment, food and social security. The labour settlements located near Varthur, Marathahalli, Kundalahalli and Mylasandra were in want of basic necessities like food, ration and water because the local governing bodies failed to send them any provisional aid guaranteed by the Karnataka government. They had to buy a can of water for five rupees because neither there were water tankers plying nor there was water supply in their localities. During the initial phase of unlock process, eighty contract labourers working on the Nagawara-Gottigere line of Namma Metro, tested positive for coronavirus and were sent to a Covid Care Centre. Physical immunity and personal hygiene could not be guaranteed to them due to the lack of concern and responsibility from government officials. The labourers received nothing even though the Labour Department allocated 15 lakhs to each Labour Officer to create awareness and distribute masks 
and sanitizers for free in labour camps. Though some of these camps received help from residents' welfare associations, such lapses from authorities aggravated their anxieties regarding their lives amidst the pandemic exigencies.

A majority of the migrant labourers decided to return back to their native villages and towns, but due to the unavailability of public transport their only resort was to walk the highways towards their 'homes'. But the governments of both the native as well as the host states restricted them from crossing the borders for the fear of spreading the contagion. On 31 March, the Bengaluru Police Commissioner ordered to shift these stranded labourers to marriage and community halls in the city that were furnished with food, accommodation and medical facilities. The government, in addition, opened Seva Sindhu Portal for the workers to register their names, and announced Shramik special trains in early May to facilitate their reverse migration to the native places. A mustering center was also set up at Tripura Vasini near Palace Grounds, where they would gather before boarding their trains. Unfortunately, the center was poorly equipped and lacked basic facilities including privacy for women. Also, there was a dearth of information on trains among the workers. Those who came to board the trains were first collectively brought to the Freedom Park and then without proper communication, were shifted to Bengaluru International Exhibition Centre (BIEC) - a convention center for 6ooo people that was converted into a relief shelter - located at Tumkur. They were being transported like "cargo" and frustrated of the lack of organization and clarity in rehabilitation mechanisms, the migrant workers demonstrated their protests on the Bengaluru-Nelamangala highway, against the state for their lack of proper planning and management strategies (Kumaran \& Krupa, 2020).

The state government offered to ensure the financial stability of migrant labourers and announced emergency relief schemes, which included a 200 crore package intended to contain the pandemic, provide a social security pension, set up fever clinics for potential COVID-19 cases and serve meals to the poor three times a day at the state-run Indira canteens, as part of its subsidized food programme. However, according to the trade unions, this allocated budget seemed to be insufficient and Indira canteens were not easily accessible for the labourers due to travel restrictions. HV Vasu, an activist and the editor of Nyaya Patha, says:

It has already been one week into the lockdown ... It is only today that the government had convened a meeting of organisations to meet the food requirements ... it did not work out. Things have just started moving now ... the government is paying the construction workers by taking money out of the state-run Karnataka Building and Other Construction Workers' Welfare Fund ... The government has not released money from its treasury but from workers' fund ... But even that is not helping to a great extent ... People are calling from everywhere saying we are hungry, especially from migrant-workers' colonies. (Nileena, 2020)

Women migrant labourers also have their own stories of agony and anguish to narrate. The women employed at garment factories in Rajarajeswari Nagar lost their jobs and thus, received no salaries to run their households. Since the government hospitals were occupied with Covid patients, pregnant women from labour camps (who cannot afford a private hospital) found it difficult to find admissions in them. Old women who received pension could not go to the post office and withdraw money due to unavailability of public transport.

This gruesome reality of migrant labourers was brought to the notice of the state by trade unions and rights organizations such as All India Central Council of Trade Unions, Karnataka Domestic Workers' Rights Union, Garment and Textile Workers' Union and Savithri Bai Phule Mahila Sanghatane, who surveyed the distress of the labourers and demanded the state to 
intervene so that the relief measures announced by the government could be hastily implemented. However, there were many flaws in the execution of these policies, which in turn aggravated the plight of the gig-economy workers. In addition to such slow violence committed by the state and the bureaucracy, the lack of empathy and sensitivity from the police force also faltered the morale of migrant labourers in the city. Though the Bengaluru police force has been instrumental in maintaining order and facilitating various processes they have had their shortcomings during this unprecedented crisis. At various labour camps the police restricted volunteers from distributing food packets and hindered their work. There were also instances where officers caned the labourers when they expressed their discontent and dissent against the manner in which they were treated in relief shelters, on roads and at railway stations (Sudhindra, 2020). Thus, the precarity of migrant labourers in Bengaluru/Bangalore mounted with the economic crisis during the pandemic, and the government failed miserably in maintaining an equilibrium state.

\section{The Rights to the City(zens)}

The phenomenon of reverse migration during the course of COVID-19 pandemic could initiate discussions and deliberations upon the fundamental rights of migrant labourers inhabiting the metropolitan cities of India. Often they seem to have less share upon the decisions that shape the city they inhabit. It is significant to understand that the current global restructuring has increased disenfranchisement, reinvigorated authoritarianism, and jeopardized democracy for these 'city'zens (a fusion of the notions of urban citizen and urban inhabitant):

[T] he new governance ethos is driven particularly by the imperative of capitalist accumulation. It eschews democratic deliberation as inefficient and inappropriate for present economic circumstances ... these new institutions and their new policy imperatives exclude local inhabitants from the decisions that shape their cities. (Purcell, 2002, p. 101)

The transformative concept of the Right to the City, introduced by Henri Lefebvre, can be employed as an analytical tool to interrogate the space occupied by the migrant labourers in Bengaluru/Bangalore. This concept is the result of the concerns regarding the decline of democracy and enfranchisement of urban dwellers. According to the 2011 Census, the construction industry in Bengaluru/Bangalore is sustained by 15 lakh migrant labourers, but whether they share a social, economic and political space equivalent to the proportion of their population is a question still left unanswered. The Bengaluru Bruhat Mahanagara Palike (BBMP) razed a labour settlement at Kariyammana Agrahara to ground, stating the reason that the residing labourers were illegal immigrants from Bangladesh just because most of them were Bangla-speaking Muslims. Even after they submitted the proofs establishing their Indian identity, they were ousted from their 'lived' spaces. The idea of the Right to the City addresses such episodes of political violence and social alienation encountered by these migrant labourers employed in various informal sectors. Lefebvre argues that the rights of an immigrant worker as an urban dweller/'city'zen should be modified and concretized so that they would be able to 'use' the center or a privileged space, instead of being scattered and estranged into ghettos (Purcell, 2002, p. 102).

During the lockdown period, the state-run institutions and private builders were apprehensive about the pending construction projects in the city which could only be completed by migrant labourers. The Namma Metro, the suburban rail and airport expansion projects were affected by the reverse migration of these labourers. Even though machinery is used for these infrastructure projects, at least 50 percent of the labour force is needed to complete the pending 
projects. Vinay Kumar HS, a junior engineer at the department (of drinking water and sanitation), says:

The delay in government infrastructure projects is mainly due to Covid-19. In the current situation, it would be impossible for the government to raise taxes equal to the pre-Covid levels as a majority of people cannot afford it now. This will make it tough for the government to pay adequate wages to the migrant labourers. (Sethulekshmi, 2020)

Their labour has been commodified for the profit of transnational corporate companies but they do not receive adequate wages for the work they do. There are real estate companies which still owe around 63 lakh rupees to these labourers for the work they did the previous year. As evident from a study on migration conducted for Karnataka Evaluation Authority and Karnataka State Government, only less than five percent of the workers is aware of their rights in the city; even the labour contractors are not aware of the Inter-state Migrant Workman (Regulation of Employment and Conditions of Service) Act 1979 that protects the rights of migrant workers in a foreign state (2017, pp. 75-92). The state also seems to disregard the need to empower them with the agency to assert their fundamental rights of being a 'city'zen in Bengaluru/Bangalore.

The indispensable instinct to fight for survival and the pending loans to repay brought over two thousand emigrated migrant workers back to Bengaluru/Bangalore. They had flown back to the city and went into home quarantine after providing local addresses - of underconstruction buildings in Sarjapur, Whitefield and other such parts of Bengaluru - to airport authorities. They set up temporary tin-sheeted shanties in order to house themselves. It is ironical to find that the sculptors of the city are not provided with rightful and adequate 'lived' spaces in the city (Bharadwaj, 2020). Apparently, the haplessness of migrant labourers increased during Covid crisis, and their rights to the space of the city remained unvocalized and unrepresented.

\section{Conclusions}

This paper is primarily an attempt to create a discourse of migrant labourers, during the lockdown and post-lockdown periods, and the economic crisis ensued by COVID-19. The course of the pandemic manifested how the governing bodies failed to observe and evaluate their living conditions. This lack of responsibility and sensitivity aggravated their concerns extending phases of lockdown. The labourers swarmed around the vans, which brought them food and other essentials, without following any precautions or the prescribed social distancing. For them it seemed to be a fight for survival, and satiating hunger was their priority above the pandemic (Thomas, 2020).

The migrant labourers have occupied the urbanscape of Bengaluru/Bangalore for almost two centuries but still they have not acquired ownership, power and agency in its urban space. Though they have played a pivotal role in constructing this global technopolis they are rendered invisible and marginalized from the mainstream urban scene due to their regional, linguistic, cultural, class and caste differences. Interrogating the urban space of Bengaluru/Bangalore exposes how the immigrant labourers and their tin-sheeted settlements are pushed against the social and spatial peripheries of this burgeoning metropolis. They are not 'authorized' to own/occupy the 'central' space of the city since that space, designated with use and exchange values, belongs to the bourgeois beneficiaries of the mainstream society. Under capitalistic ventures, labour, urban space and urban governance have become exclusive commodities, which yield profits for those in power. The labour and the body of a labourer are 'used' by the state and private capitalist institutions alike; they devour the benefits reaped out of their labour but deny to pay them appropriately or provide faculties for their upward social mobilization. Evidences show 
7 | Living on the Edge: Interrogating Migrant Labourer Lives of Bengaluru/Bangalore

that the immigrant labourers are perceived as the city's necessary 'Other' who are needed to build and re-build the city but barely finds any representation in the planning grids of urban architects.

The United Nations Conference on Housing and Sustainable Development (Habitat III), held in Quito, Ecuador in October 2016 declared the New Urban Agenda (NUA) - that was adopted as the guideline for urban development for the next twenty years - with the vision of 'cities for all'. But in reality, they are denied a dignified and equal access to the urban space and spatial politics. The experiences and negotiations of the migrant labourers within the 'lived' city explains how they are not given adequate share of power in the democratic control of the city. Recapitulating the Lefebvrean concept of the 'Right to the City' asserts the need for these labourers to define their agency and power to assert their rights to have a dignified access to urban space, demand social justice and become a meaningful stakeholder in the democratic control of the city of Bengaluru/Bangalore, where social inequalities prevail unabatedly. Time has come to reclaim the city as a co-created space, detached from the spatial inequalities and other hazardous effects of commodification and capitalism.

\section{References}

Bharadwaj, A. K. V. (2020, July 30). Mounting loans and lack of jobs make migrant workers vulnerable to human traffickers. The Hindu. https://www.thehindu.com/news/cities/bangalore/mounting-loansand-lack-of-jobs-make-migrant-workers-vulnerable-to-human-traffickers/article32224753.ece

Bhat, P. (2020, August 3). Unfazed by Stigma. The News Minute. https://www.thenewsminute.com/article/unfazed-stigma-bengaluru-migrant-labourers-queuedonate-blood-129959

Council for Social Development. (2017, June). Evaluation Study of Migration of Labour to and from Karnataka. Government of Karnataka.

COVID-19: Number of infected contract labourers in Bengaluru Metro climbs to 80. (2020, July 14). Bangalore Mirror. https://bangaloremirror.indiatimes.com/bangalore/others/covid-19-number-of-infectedcontract-labourers-in-bengaluru-metro-climbs-to-8o/articleshow $/ 76962637 . \mathrm{cms}$

Karnataka opens relief centres under lockdown for migrant labourers, vulnerable groups. (2020, July 17). Deccan Herald. https://www.deccanherald.com/state/karnataka-opens-relief-centres-underlockdown-for-migrant-labourers-vulnerable-groups-862495.html

Kumaran, P., \& Krupa, P. L. (2020, May 5). Even after 40 plus days of hard lockdown, it looks like Karnataka government has no plan $B$. Bangalore Mirror. https://bangaloremirror.indiatimes.com/bangalore/cover-story/even-after-40-plus-days-of-hardlockdown-it-looks-like-karnataka-government-has-no-plan-b/articleshow/75542938.cms

Lefebvre, H. (1992). The Production of Space (D. Nicholson-Smith, Trans.). Wiley-Blackwell.

Nair, J. (2005). The Promise of Metropolis. Oxford University Press.

Nileena, M. S. (2020, April 3). Bengaluru's workers suffer as Karnataka's response to COVID-19 marked by delays, inefficiency. The Caravan. https://caravanmagazine.in/health/bengaluru-workers-suffer-askarnataka-response-covid-marked-by-delays-inefficiency

Peter, P. (2020, July 22). Bengaluru: Migrant workers returning in style. The Times of India. https://timesofindia.indiatimes.com/city/bengaluru/desperate-for-complete-projects-builders-areflying-migrant-back/articleshow/77095067.cms 
PTI. (2020, March 31). COVID-19 crisis: Bengaluru police told to shift stranded migrant labourers to marriage halls. The New Indian Express.

https://www.newindianexpress.com/cities/bengaluru/2020/mar/31/covid-19-crisis-bengalurupolice-told-to-shift-stranded-migrant-labourers-to-marriage-halls-212390o.html

Purcell, M. (2002). Excavating Lefebvre: The right to the city and its urban politics of the inhabitant. GeoJournal, 58(2/3), 99-108. https://doi.org/10.1023/b:gejo.0000010829.62237.8f

Ranjini Rao, H. S. (2020, May 19). Bangalore's Informal Labour Markets. Indian Institute of Management Bangalore. https://www.iimb.ac.in/turn_turn/bangalore-informal-labour-markets.php

Sethulekshmi, M. S. (2020, July 25). "Ensure welfare of migrant labourers, projects depend on their return." Deccan Herald. https://www.deccanherald.com/specials/point-blank/ensure-welfare-of-migrantlabourers-projects-depend-on-their-return-865418.html

Shashidhar, H. (2003). A History of Migration to Bangalore. Artha Journal of Social Sciences, 2(1), 70-84. https://doi.org/10.12724/ajss.3.7

Smita, P., Prameela, V., Banu, S., Meenakshi, K. G., Manjunath, H., \& Prema, T. (2014). The Socio-Economic Status of Migrant Construction Workers in Bangalore and Intervention Plan to Improve Their Livelihoods. Urban India, 34(1), 112-130. http://www.shram.org/uploadFiles/20150417055241.pdf

Sudhindra, D. (2020, July 22). We saw two extremes of Bengaluru's police, say lockdown relief... Citizen Matters, Bengaluru. https://bengaluru.citizenmatters.in/covid-police-role-relief-volunteers-48405

Thomas, B. (2020, April 17). Living on the edge: Migrant workers in Bengaluru say they are running out of patience. Bangalore Mirror. https://bangaloremirror.indiatimes.com/bangalore/cover-story/livingon-the-edge-migrant-workers-in-bengaluru-say-they-are-running-out-ofpatience/articleshow/75189239.cms

United Nations. (2016, October). New Urban Agenda.

Woodruff, G. M. (1960). Family Migration into Bangalore. Economic and Political Weekly, 12(4-5-6), 163-172. https://www.epw.in/system/files/pdf/196o_12/4-5-6/family_migration_into_bangalore.pdf

Navami T. S. is currently pursuing her $\mathrm{PhD}$ in English at the Department of Humanities and Social Sciences, Indian Institute of Technology Kharagpur, West Bengal, India. The prime area of her research is urban space and spatiality in contemporary Indian writing in English. 